\title{
The Global Financial Crisis’ Impact on Short-term Performance of IPO: The Case Study of New Zealand
}

\section{Firms’ IPOs}

\author{
Fitriya Fauzi (Corresponding author) \\ The University of Waikato, Waikato Management School, New Zealand \\ Private Bag 3105, Hamilton 3240, New Zealand \\ E-mail: ff21@waikato.ac.nz
}

Nirosha Hewa Wellalage

The University of Waikato, Waikato Management School, New Zealand

Private Bag 3105, Hamilton 3240, New Zealand

Stuart Locke

The University of Waikato, Waikato Management School, New Zealand

Private Bag 3105, Hamilton 3240, New Zealand

Received: May 22, 2012 Accepted: August 3, $2012 \quad$ Published: December 1, 2012

doi:10.5296/ajfa.v4i2.1829ＵRL: http://dx.doi.org/10.5296/ajfa.v4i2.1829

\begin{abstract}
The global financial crisis had major effects on the New Zealand (NZ) capital market, financial system and economy. It prompted responses across the full range of the NZ Securities Commission and the NZ Reserve Bank policies, including amendment of the Securities Act 2009, monetary policy, liquidity management and prudential policies. This paper investigates the impact of global financial crisis on short-term performance of New Zealand firms' Initial Public Offering (IPOs) for the period before, during and after the crisis. Using New Zealand firms' IPOs from 2006 to 2010, this study employs an event study method which applies market adjusted return and market model to calculate abnormal returns. Two-sample mean-comparison test and the Multivariate Regression Model (MVRM) are used in this study. The result reveals that there is a significant difference between short-term IPOs' performance before, during and after the global financial crisis. Further, the MVRM result
\end{abstract}




\section{Macrothink}

supports the two-sample mean-comparison test result in which 2008 and 2009 periods have a negative significant impact on abnormal returns, suggesting that it has underperformed the average market returns. This study provides recent evidence for New Zealand IPOs' short-run performance during the global financial crisis. A study of New Zealand is interesting as most previous studies consider mature markets like the US and the UK.

Key words: Short-term performance, Initial Public Offering (IPOs), global financial crisis, event study, New Zealand firms.

JEL Classification: G14 


\section{Introduction}

One of the most important events in the life of a firm, and one of particular interest to institutional investors, is the transition from being a private to a public company. As public companies, they need to offer their shares to the public through Initial Public Offering (IPOs), the first sale of stocks by an unlisted firm to the public through stock markets. IPOs allow private firms to raise a larger pool of equity capital than is available from any other source. Furthermore, they allow a firm to raise many times that amount in one offering and hence improve their overall financial condition. However, an IPO involves financial costs and managerial costs. Therefore, the benefit of going public must be weighed against the massive costs of setting up an IPO. For example, in New Zealand the costs of raising equity through IPOs should be no more than 6-8\% of the fund raised in the New Zealand Stock Exchange (NZX), depending on each firm's circumstances. The NZX listing fees are only a small part of IPOs' cost. Further, not only do IPOs provide benefit to the issuers but also IPOs provide an opportunity for investors to invest in the share of growth of the firm. An IPO is conducted in the primary stock markets, which primarily deal with the issuance of new securities.

The New Zealand (NZ) IPOs conduct activities in the NZSX, which is the premier equities market. The NZ IPO history can be traced back to the beginning of 1900, when Sanford Limited listed their stock on the NZSX in 1904. However, after the first IPOs, there were no further IPOs until Hallesntein Glassons Holding Limited listed their stock in 1947; after that, NZ firms started to list their shares on the stock market. The performance of IPOs depends on firms' specific factors, and common factors, for example a firm's prestige and economic conditions (such as the global financial crisis which happened the beginning of 2007).

The global financial crisis in 2007 and 2008 was started by the United States subprime crisis in 2006. The crisis began with the default of mortgage loans in the US, and spread quickly to affect all the US sectors and other countries, particularly those with tight trade links to the US. To minimise the impact of the global financial crisis, the New Zealand government made many changes aimed at pulling its regulations and policies in line with international standards to encourage confidence and ease of investment in New Zealand. One of the changes made by the New Zealand government to encourage investment activities in its capital markets was to review the Securities (Disclosure) Amendment Act 2009. The purpose of amending the Act was to attract and retain more companies to invest and to do business in New Zealand, as this activity would strengthen the New Zealand economy.

The question is whether New Zealand's response to the global financial crisis has done enough to induce investors and businesses to enter and operate in New Zealand. One indicator is the NZ Roy Morgan Consumer Confidence Survey 2009, which indicated that consumer confidence rose to its highest level in early September 2009 from the level in March 2008, which was the first quarter in which New Zealand entered the recession. Predictions were for the New Zealand economy to exit recession in 2010. Nevertheless, there are barriers that remain, which prevent businesses seeking to operate in New Zealand. On 16 December 2009, the Government set up a Capital Market Development Taskforce to review the current state of New Zealand's capital markets, the international context, future risks and 
opportunities and key changes necessary to deliver the best possible financial system for New Zealand (Ministry of Economic Development, 2012). The Taskforce believes its recommendations will significantly improve the contribution that capital markets make to New Zealand's economic growth and New Zealanders' well-being.

The short-term performance of IPOs has become the focus of attention. Reilly (1977), Aggarwal and Rivoli (1990), Ritter (1991), and Loughran and Ritter (1995) report negative aftermarket returns for IPOs in the US. Similar to the US and Australia (Finn \& Higham, 1988), New Zealand (Firth, 1997; Loughran \& Ritter, 2006) is found to have a negative significant aftermarket returns. In addition, over the last 40 years the US IPOs have enjoyed first-day returns of over 18\% (Loughran \& Ritter, 2006) and Australia for 12.1\% for over 20 years (Lee, Taylor, \& Walter, 1996), while New Zealand IPOs have experienced initial returns of 23\% over the past 20 years (Loughran, Ritter, \& Rydqvist, 2006). Short-run performance of IPOs has gone through extensive observation and it has been found that regardless of the method of pricing, IPOs tend to yield substantial returns in the days (and sometimes weeks) immediately following issue.

Though the New Zealand IPOs have experienced positive abnormal returns over the past 20 years (Loughran et al., 2006), the data reveal that during the global financial crisis the New Zealand IPOs are exhibiting negative abnormal return. The New Zealand IPOs average abnormal return for 2006, 2007, 2008, 2009 and 2010 is $-1.21 \%,-0.60 \%,-0.20 \%,-0.78 \%$ and $0.86 \%$ respectively, and the overall average abnormal initial return during 2006 to 2010 is $-0.47 \%$. An abnormal return can be positive or negative, depending on whether the stock outperformed or underperformed the average market performance, and thus a positive abnormal return indicates capital gain while a negative abnormal return indicates capital losses against market performance. This provides a crude measure of the stock's performance at a specific time, but it does not take into consideration fluctuations that maturally occur over a given period. To account for these normal variations, the cumulative abnormal return is defined as the sum of all abnormal returns over a defined period of time. The negative abnormal return for New Zealand IPOs suggests that IPO stocks underperformed compared to the market performance.

The purpose of this paper is to investigate the short-term stock price behaviour of IPOs in New Zealand. A Study of New Zealand firms is interesting because a large number of the quoted firms are relatively young and have been listed for less than twenty years. New issues represent major activities of the NZSX and they are listed on the full board in contrast to the US IPOs that typically trade on the over-the-counter market.

\section{Literature Review}

The international evidence on short-run IPOs' performance is mixed. The existing studies show that the initial underpricing is common for both developed and developing stock markets. This phenomenon is also known as short-run underpricing, as the company appears to be "leaving money on the table". Ritter (1991), Keasey and Short (1992), Ibbotson, Sindelar and Ritter (1994), Loughran and Ritter (1995), Ritter and Welch (2002), and Ljungqvist and Wilhelm (2003) all found underpricing in the U.S. market. Similar to the US, 
Lee et al. (1996) and Gong and Sekhar (2001) reported underpricing for the Australian market; Husson and Jacquillat (1989), Levis (1993), and Kunz and Aggarwal (1994) revealed underpricing for other developed countries, such as European countries. Firth (1997), and Loughran and Ritter (2006) also found the same result for the New Zealand market. Cheung and Vos (1992) found that more than 28\% of IPOs in the NZ share market were underpriced, when only $15 \%$ of the US IPOs were. This may be due to the effect of differences of legal liability. Surprisingly, this study reveals that during the global financial crisis, the New Zealand IPOs exhibit different patterns from other countries and from previous times, as the New Zealand IPOs yield negative abnormal returns.

In a study of a developed market, Aggarwal and Rivoli (1990) found negative aftermarket performance of $-13.73 \%$ in the first year following the initial offering for 1,435 IPOs in the period from 1977 to 1987. Likewise, Ritter (1991) found a significant mean market-adjusted return of $-29.13 \%$ for a sample of 1,526 IPOs over the period 1975 to 1984 . Further, Ritter reports that the underperformance is concentrated among younger firms and firms that went public in the heavy-volume years. There are a number of possible explanations for the short-run IPO phenomenon. One explanation is the rationing of a limited number of shares available in IPOs. The number of shares subscribed often far exceeds the number of shares available; this leads to a potential "winner's curse" for investors, because the only option is to buy shares in less desirable IPOs' stocks'; therefore, the IPO sets a low price to attract investors (Rock, 1986).

However, the aftermarket is not immediately efficient in valuing newly issued securities, hence the abnormal returns that ensue to IPOs investors are the result of a temporary overvaluation by investors in the early trading (Aggarwal \& Rivoli, 1990). This is consistent with the "impresario" hypothesis, or the fads hypothesis (Shiller, 1990), which argues that the market for IPOs is subject to fads and that IPOs are underpriced by the investment bankers (the impresarios) to create the appearance of excess demand. This hypothesis predicts that the greater the initial return at the IPOs date, the greater the degree of subsequent correction of overpricing by investors will tend to be and the smaller subsequent returns should be.

Further, underpricing can create a "cascade” effect, whereby initial investors are enticed to buy in, in the hope that more investors will follow (Ritter, 1998; Welch, 1992). However, the underperformance of IPOs in the aftermarket has not been documented in all studies and the international evidence is varied (Loughran, Ritter, \& Rydqvist, 1994). These international variations are due, in part, to the differences in regulations, contractual mechanisms, and characteristics of companies going public (Firth, 1997). The window of opportunity hypothesis predicts that firms going public in high volume periods are more likely to be overvalued than other IPOs (Loughran \& Ritter, 1995; Ritter, 1991). This has the testable implication that the high-volume periods should be associated with the lowest long-run returns; this pattern exists in the US.

In addition, the IPOs' underperformance is also positively related to the size of discretionary accruals in the fiscal year of the IPOs, because investors may misinterpret high earnings reported at the time of the offering and consequently overvalue the new issues (Teoh, Welch, 
\& Wong, 1998). Then, when high pre-issue earnings are not sustained, disappointed investors revalue the firm downwards. This scenario suggests that issuers have unusually high income-increasing accounting adjustments and unusually poor post-issue earnings and return performance. Overall, the investors' sentiments towards IPOs are an important factor in the underperformance or outperformance of the IPOs.

To investigate the IPOs’ performance, previous studies employ an event study analysis. An event study relates to the information uncertainty in the market; when the market absorbs particular information, it will reflect in the firm value, which is indicated by the stock price movement. The examples of information affecting stock price are earning announcements, stock split announcements, and mergers and acquisitions. Event study analysis, first introduced by Doley (1933), examined the impact of stock split on the stock price. In his study, Doley found a significant difference in the stock price movement in which the price increased in 57 of the cases and declined in only 26 of the cases. Further, MacKinlay (1997) noted that studies in the event study field have been conducted since its initial momentum by Myers (1948), Barker (1956) and Ashlery (1962).

However, event study has been popular since the seminal work of Ball and Brown (1968) and Fama, Fisher, Jensen and Roll (1969). They introduced the methodology of the event study that has been employed by most researchers until now. Ball and Brown (1968) examined the impact of earning announcements, and Fama et al. (1969) examined the impact of stock split on the stock price, using 29 months before the split was announced to 30 months after as the event period, and the abnormal return was calculated using the market model. The result revealed that the stock price quickly adjusted to the split announcement, and no investors should gain abnormal return from the split announcement.

The null hypothesis is that the global financial crisis has no impact on short-term performance of IPO, and the hypotheses proposed are as follow:

$H_{01}: C A A R_{2006(1, T)}$ is not significantly different from $C A A R_{2007(1, T)},(T=1 \ldots 20$ and $1 \ldots 60)$

$H_{02}: C_{2 A A R_{2007(1, T)}}$ is not significantly different from $C A A R_{2008(1, T),}(T=1 \ldots 20$ and $1 \ldots 60)$

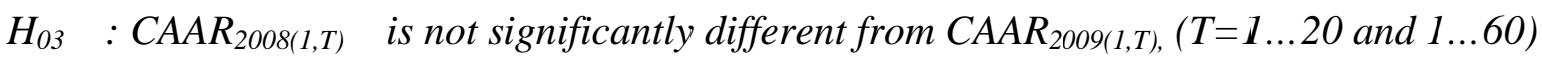

$H_{04}: C_{2 A A R_{209(1, T)}}$ is not significantly different from $C A A R_{2010(1, T),}(T=1 \ldots 20$ and $1 \ldots 60)$

\section{Methodology}

\subsection{Data}

This study uses New Zealand firms' IPOs for the period of 2006-2010 collected from the NZX deep archive. Firms used in this paper are those who listed their IPO only on the NZSX. The NZSX market is suited to large and established enterprises. From 2006 to 2010, there were only 23 IPOs on the NZSX. Though only 23 firms were observed, the sample may do well in capturing aggregate leverage in the country because the listed firms can be used to represent the NZ IPOs during the global financial crisis. 


\subsection{Method}

An event study method is employed in this paper to analyse short-term performance of IPOs; market adjusted returns and market model are used to calculate abnormal returns. According to Brown and Warner (1980), different abnormal return benchmarks used in the event studies give less benefit, which in fact might worse off the result. Further, Chandra, Moriarty and Willinger (1990) suggested that the mean adjusted returns and market adjusted returns have a power equal to the market and risk adjusted returns in estimating parameters; however, Binder affirms that the mean adjusted returns is less powerful than the market adjusted returns and the market and risk adjusted returns in estimating parameters. Likewise, Castillo (2004) suggests that the market corrected model and the market model minimise the variance of the abnormal return by removing the portion of the returns related to the market movements; hence, this increases the wider possibility of detecting the event effect.

Market adjusted returns are calculated as the return difference between stock return and market return (Brown \& Warner, 1985).

$$
A_{i t}=R_{i t}-R_{m t}
$$

Where $R_{i t}$ and $R_{m t}$ are the period $t$ returns on security $i$ and the market portfolio, this method only requires the return market.

Market model is calculated using Ordinary Least Square (OLS) regression estimation (MacKinlay, 1997). This method controls for the risk (beta) of the stock and the movement of the return market during the period estimated. The benefit of using the market model will depend on the $\mathrm{R}^{2}$ regression; the higher $\mathrm{R}^{2}$, the greater is the reduction in the variance of abnormal returns, which increases the power to detect the abnormal performance.

$$
\begin{gathered}
R_{i t}=\alpha_{i}+\beta_{i} R_{m t}+\varepsilon_{i t} \\
E\left(\varepsilon_{i t}=0\right) \quad \operatorname{Var}\left(\varepsilon_{i t}\right)=\sigma_{\varepsilon_{i}}^{2}
\end{gathered}
$$

Where $R_{i t}$ and $R_{m t}$ are the period $t$ returns on security $i$ and the market portfolio, $\varepsilon_{i t}$ is the zero mean disturbance term. $\alpha_{i}, \beta_{i}, \sigma_{\varepsilon_{i}}^{2}$ are the parameters of the market model.

According to Blume (1975), the estimated beta deriving from the historical data is biased, and it may affect the empirical results. Therefore, the estimated beta has to be adjusted to avoid bias, and the adjustment of beta is important since it will be used to foreicast the future beta for a security in which it will be used to estimate its market risk. Furthermore, the beta changes over time as the uncertainty arises in the value of the expected return, which can be the result of bias; therefore several time periods are used to measure the beta. If the true beta follows a linear trend, it can be easily shown that the estimated beta is unbiased, so the results are more accurate. In addition, Blume's method is generally appropriate for any conditions arising in the market. 
A linear regression is a common method used in the beta estimation, and the adjusted beta is calculated using Blume's method, to acquire unbiased beta for the forecast period, and therefore the results are more accurate. The linear regression for beta is:

$$
\beta_{i 2}=a+b \beta_{i 1}+\varepsilon_{i 2}
$$

Where $\beta_{i 1}$ is the beta of security $i$ in time period $1, \beta_{i 2}$ is the beta of security $i$ in time period 2 and $\varepsilon_{i 2}$ is the error term. The formula 1 is used to calculate the beta in time period 2 . The beta in time period 2 ( $21^{\text {st }}$ trading day after listing day to $60^{\text {th }}$ trading day), are regressed on the corresponding beta in the time period 1 (second part of 20 days). Figure 3.3.1 depicts the length of the event window and the estimation window used in this paper.

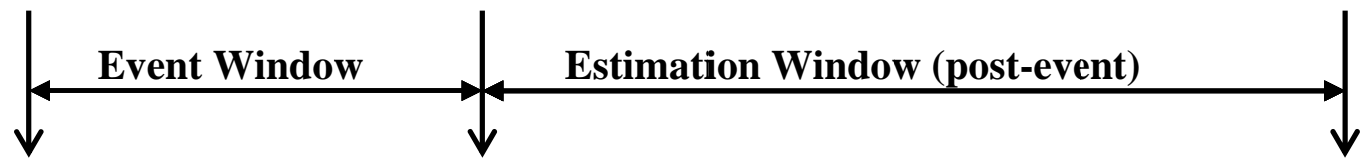

$\mathbf{T}_{\mathbf{0}} \quad \mathbf{T}_{1}$

$\mathrm{T}_{0}$ : Listing day to $20^{\text {th }}$ trading day

$\mathrm{T}_{0}: 21^{\text {st }}$ trading day (after $1^{\text {st }}$ day trading) to $60^{\text {th }}$ trading day

Figure 3.3.1. Abnormal return estimation using the market model

The event window is the number of trading days following the listing day that are considered necessary to capture both the leakage and the time needed for the information to be absorbed by the market. The length of the event window is a matter of judgement for the researcher, and it is preferable to have the smallest number of days in the event window as possible, because multiple events within an event window may occur and affect the significance of result. Furthermore, to calculate the abnormal return variation over the event window and the estimation window, the abnormal returns in the sample firms are aggregated to draw overall inferences, and the aggregation is calculated through time and across securities. The cumulative abnormal return (CAR) is used to accommodate a multiple period event window.

$$
\begin{gathered}
C A R_{i}=A R_{i, t 1}+\cdots+A R_{i, t 2} \\
C A R_{i}\left(\tau_{1}, \tau_{2}\right)=\sum_{\tau=\tau_{1}}^{\tau_{2}} A R_{i \tau}
\end{gathered}
$$

Under the null hypothesis, $\mathrm{H}_{0}$, that the event has no impact on the behaviour of returns (mean or variance) in observation length of the event window (MacKinlay, 1998):

$$
A R_{i \tau} \sim N\left(0, \sigma_{i}^{2}\left(A R_{i \tau}\right)\right)
$$

The variance of $C A R_{i}$ is:

$$
\sigma_{i}^{2}\left(\tau_{1}, \tau_{2}\right)=\left(\tau_{2}-\tau_{1}+1\right) \sigma_{\varepsilon_{i}}^{2}
$$


The distribution of the $C A R$ under $\mathrm{H}_{0}$ is no abnormal return, then:

$$
C A R_{i}\left(\tau_{1}, \tau_{2}\right) \sim N\left(0, \sigma_{i}^{2}\left(\tau_{1}, \tau_{2}\right)\right)
$$

The aggregation is calculated through time and across securities

$$
\begin{aligned}
& A A R_{t}=A R_{i, t 1}+\cdots+A R_{i, t 2} \\
& A A R_{t}=\frac{1}{N} \sum_{i=1}^{N} A R_{i} \\
& C A A R_{t}=\sum_{t=t 1}^{t 2} A A R_{t}
\end{aligned}
$$

The variance of the cumulative average abnormal returns (CAAR) is:

$$
\sigma_{i}^{2}\left(\tau_{1}, \tau_{2}\right)=\left(\tau_{2}-\tau_{1}+1\right) \sigma_{\varepsilon_{i}}^{2}
$$

The distribution of the $C A A R$ under $\mathrm{H}_{0}$ is no abnormal return, then:

$$
\operatorname{CAAR}_{i}\left(\tau_{1}, \tau_{2}\right) \sim N\left(0, \sigma_{i}^{2}\left(\tau_{1}, \tau_{2}\right)\right)
$$

To support the two-sample mean-comparison test, this study employs a Multivariate Regression Model (MVRM) methodology, which was first introduced by Gibbons (1982), and is used to measure the effect of new information on asset prices. Binder (1985) uses MVRM applying Fama et al.'s (1969) method to measure abnormal return, and outlines the advantage of the MVRM method over other event study methodologies. The MVRM methodology begins by parameterising the abnormal returns $\gamma_{i a}$ in the individual return equations (Binder, 1985):

$$
\tilde{R}_{i t}=\alpha_{i}+\beta_{i} \tilde{R}_{m t}+\sum_{a=1}^{A} \gamma_{i a} D_{a t}+\tilde{u}_{i t}
$$

While Binder (1985) uses dummy variables to specify the announcement effect, this study uses year dummy to specify which year has significant impact on abnormal return of IPO. When the explanatory variables in the return generating process are the same for each of the $N$ stocks the system of return equations is:

$$
\begin{gathered}
\tilde{R}_{1 t}=\alpha_{1}+\beta_{1} \tilde{R}_{m t}+\sum_{a=1}^{A} \gamma_{1 a} D_{a t}+\tilde{u}_{1 t} \\
\tilde{R}_{2 t}=\alpha_{2}+\beta_{2} \tilde{R}_{m t}+\sum_{a=1}^{A} \gamma_{2 a} D_{a t}+\tilde{u}_{2 t} \\
\tilde{R}_{N t}=\alpha_{N}+\beta_{N} \tilde{R}_{m t}+\sum_{a=1}^{A} \gamma_{N a} D_{a t}+\tilde{u}_{N t}
\end{gathered}
$$

After testing the MVRM for each firm, this study applies joint hypothesis testing for all firms and all announcements, and then the portfolio return equation is: 


$$
\tilde{R}_{p t}=\alpha_{p}+\beta_{p} \tilde{R}_{m t}+\sum_{a=1}^{A} \gamma_{p a} D_{a t}+\tilde{u}_{p t}
$$

\section{Findings}

Table 1 presents descriptive statistics for all year observed. As can be seen, apart from 2006, the average market adjusted returns for all years observed yield negative returns, with a range from -0.0039 to -0.0767 . This is significantly different from zero, suggesting that the IPOs firms' performance was under the market performance. However, only 2007 and 2009 yield negative average abnormal returns for the market model. The results differ solely because of the different calculation used for each method, in which market adjusted return did not take inflation into account, whereas during that period New Zealand exhibited an upward sloping yield curve; the longer term interest rates are higher than short-term rates. This means long-term bond was favoured over short-term bond. Similarly, stocks are more volatile in terms of risk and return, and because of the interest rates, investors favoured long-term investment, which thus resulted in negative abnormal returns for IPOs compared with market model. However, the different calculation methods provide greater robustness for the analysis, and hence provide a better explanation than having only one method.

Table 1. Descriptive Statistics

\begin{tabular}{rccccccccc}
\multicolumn{1}{c}{ Market Adjusted Returns } & \multicolumn{3}{c}{ Market Model } \\
\hline CAAR & Obs & Mean & Std.Dev. & Min & Max & Mean & Std.Dev. & Min & Max \\
\hline 2006 & 60 & 0.0447 & 0.0175 & -0.0121 & 0.0751 & 0.0084 & 0.0109 & -0.0154 & 0.0344 \\
2007 & 60 & -0.0698 & 0.0417 & -0.1245 & 0.0017 & -0.0148 & 0.0189 & -0.0434 & 0.0248 \\
2008 & 60 & -0.0360 & 0.0368 & -0.1260 & 0.0318 & 0.0177 & 0.0219 & -0.0197 & 0.0602 \\
2009 & 60 & -0.0767 & 0.0431 & -0.1418 & 0.0042 & -0.0017 & 0.0111 & -0.0328 & 0.0245 \\
2010 & 60 & -0.0039 & 0.0637 & -0.2522 & 0.0740 & 0.0561 & 0.0700 & -0.0946 & 0.1787 \\
\hline
\end{tabular}

Table 2 and Table 3 present the average abnormal returns (AAR) and the cumulative average abnormal returns (CAAR). However, there are considerable variations in the abnormal returns across new issuance and so it is of interest to examine whether these variations are indeed reflections of IPOs performance. Furthermore, the t-statistics for the average abnormal returns and cumulative abnormal returns after listing day using market adjusted return and market model respectively are provided. The abnormal returns are shown for day 1 to day 20 after the issuance. The average abnormal return in the first day to fifth day is negative, reflected in the decline of CAAR. By day 20, the CAAR is -0.0078 , showing a substantial decline in the investment value. The results here indicate a continuing deterioration in performance for New Zealand IPOs within a range of 20 trading days after listing day. However, the results only show short-term performance of IPOs, and probably investors who hold the stock for longer periods may make substantial profit. Overall, the t-statistics test, for market adjusted returns and market model, is different from zero and insignificant for all the day observed. Abnormal returns from first trading day to the twentieth trading day are 
negative, suggesting that investors react negatively to the IPO. The negative reaction may be due to some reasonable conditions, for example uncertainty of the economic conditions, reduced reputation of investment bankers, and hence markets have negative sentiments.

Table 2. Average abnormal returns after listing day

\begin{tabular}{ccccccc}
\hline \multirow{2}{*}{ Days } & \multicolumn{7}{c}{ Market Adjusted Return } \\
\cline { 2 - 7 } & AAR & std.dev & t-test & CAAR & std.dev & t-test \\
\hline 1 & -0.0047 & 0.0214 & -0.2187 & -0.0047 & 0.0214 & -0.2187 \\
2 & -0.0006 & 0.0243 & -0.0231 & -0.0052 & 0.0243 & -0.2156 \\
3 & -0.0018 & 0.0278 & -0.0657 & -0.0071 & 0.0278 & -0.2546 \\
4 & -0.0002 & 0.0226 & -0.0075 & -0.0072 & 0.0226 & -0.3198 \\
5 & 0.0129 & 0.0377 & 0.3416 & 0.0056 & 0.0377 & 0.1496 \\
6 & 0.0017 & 0.0205 & 0.0844 & 0.0074 & 0.0205 & 0.3590 \\
7 & -0.0067 & 0.0162 & -0.4131 & 0.0007 & 0.0162 & 0.0430 \\
8 & -0.0129 & 0.0808 & -0.1599 & -0.0122 & 0.0808 & -0.1513 \\
9 & 0.0102 & 0.0215 & 0.4769 & -0.0020 & 0.0215 & -0.0920 \\
10 & 0.0218 & 0.0930 & 0.2339 & 0.0198 & 0.0930 & 0.2127 \\
11 & 0.0049 & 0.0224 & 0.2191 & 0.0247 & 0.0224 & 1.1014 \\
12 & -0.0118 & 0.0644 & -0.1832 & 0.0129 & 0.0644 & 0.2005 \\
13 & 0.0021 & 0.0608 & 0.0349 & 0.0150 & 0.0608 & 0.2472 \\
14 & 0.0033 & 0.0263 & 0.1246 & 0.0183 & 0.0263 & 0.6957 \\
15 & -0.0006 & 0.0278 & -0.0223 & 0.0177 & 0.0278 & 0.6365 \\
16 & -0.0024 & 0.0177 & -0.1371 & 0.0153 & 0.0177 & 0.8639 \\
17 & -0.0053 & 0.0170 & -0.3139 & 0.0099 & 0.0170 & 0.5861 \\
18 & -0.0165 & 0.0440 & -0.3757 & -0.0066 & 0.0440 & -0.1496 \\
19 & -0.0005 & 0.0259 & -0.0181 & -0.0070 & 0.0259 & -0.2724 \\
20 & -0.0007 & 0.0201 & -0.0369 & -0.0078 & 0.0201 & -0.3870 \\
\hline
\end{tabular}

*sig. at $10 \%$ level, $* *$ sig. at $5 \%$ level, and ${ }^{* * *}$ sig. at $1 \%$ level 
Table 3. Average abnormal returns after listing day

\begin{tabular}{ccccccc}
\hline \multirow{2}{*}{ Days } & \multicolumn{6}{c}{ Market Model } \\
\cline { 2 - 7 } & AAR & std.dev & t-test & CAAR & std.dev & t-test \\
\hline 1 & -0.0044 & 0.0225 & -0.1965 & -0.0044 & 0.0225 & -0.1965 \\
2 & -0.0030 & 0.0273 & -0.1094 & -0.0074 & 0.0273 & -0.2715 \\
3 & -0.0057 & 0.0261 & -0.2164 & -0.0131 & 0.0261 & -0.5000 \\
4 & -0.0012 & 0.0214 & -0.0563 & -0.0143 & 0.0214 & -0.6674 \\
5 & 0.0132 & 0.0374 & 0.3525 & -0.0011 & 0.0374 & -0.0289 \\
6 & 0.0025 & 0.0185 & 0.1374 & 0.0015 & 0.0185 & 0.0790 \\
7 & -0.0069 & 0.0148 & -0.4640 & -0.0054 & 0.0148 & -0.3659 \\
8 & -0.0119 & 0.0710 & -0.1680 & -0.0174 & 0.0710 & -0.2445 \\
9 & 0.0118 & 0.0222 & 0.5337 & -0.0055 & 0.0222 & -0.2484 \\
10 & 0.0215 & 0.0895 & 0.2406 & 0.0160 & 0.0895 & 0.1790 \\
11 & 0.0032 & 0.0198 & 0.1605 & 0.0192 & 0.0198 & 0.9686 \\
12 & -0.0137 & 0.0696 & -0.1968 & 0.0055 & 0.0696 & 0.0792 \\
13 & 0.0037 & 0.0619 & 0.0591 & 0.0092 & 0.0619 & 0.1481 \\
14 & 0.0030 & 0.0184 & 0.1633 & 0.0122 & 0.0184 & 0.6611 \\
15 & 0.0003 & 0.0205 & 0.0154 & 0.0125 & 0.0205 & 0.6091 \\
16 & -0.0028 & 0.0179 & -0.1552 & 0.0097 & 0.0179 & 0.5436 \\
17 & -0.0028 & 0.0173 & -0.1636 & 0.0069 & 0.0173 & 0.3984 \\
18 & -0.0120 & 0.0404 & -0.2984 & -0.0052 & 0.0404 & -0.1278 \\
19 & 0.0023 & 0.0248 & 0.0946 & -0.0028 & 0.0248 & -0.1137 \\
20 & 0.0032 & 0.0189 & 0.1704 & 0.0004 & 0.0189 & 0.0214 \\
\hline
\end{tabular}

*sig. at 10\%level, **sig. at $5 \%$ level, and ${ }^{* * *}$ sig. at $1 \%$ level

Table 4 presents the two-sample mean-comparison test for 20 trading days and 60 trading days after the issuance. Apart from the market model's 20 trading days, the results show no significant different between 20 trading days and 60 trading days using two different methods of abnormal return calculation. Further, the results exhibit significant coefficients for all years in which they are compared, and thus this study rejects the null hypothesis that the CAAR 2006

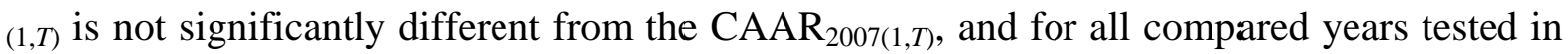
this study. Hence, it can be concluded that there is a significant difference of the CAAR for the years compared. The different CAAR may be the result of the global financial crisis, which happened during 2008 and 2009; however, other causes seem to be possible in contributing to the difference. 


\section{Macrothink Institute ${ }^{T M}$}

Table 4. Two-sample mean-comparison test

20 trading days

60 trading days

\begin{tabular}{lcccc}
\hline $\boldsymbol{C A A R}$ & $\boldsymbol{M A R}$ & $\boldsymbol{M M}$ & $\boldsymbol{M A R}$ & $\boldsymbol{M M}$ \\
\hline 2006 \& 2007 & $7.3821^{* *}$ & $1.8540^{* *}$ & $19.6080^{* *}$ & $8.2590^{* *}$ \\
2007 \& 2008 & $-3.6041^{* *}$ & 0.9994 & $-4.7130^{* *}$ & $-8.7135^{* *}$ \\
2008 \& 2009 & $4.0123^{* *}$ & 1.2621 & $5.5583^{* *}$ & $6.1126^{* *}$ \\
$2009 \& 2010$ & $-4.4418^{* *}$ & 1.4409 & $-7.3278^{* *}$ & $-6.3189^{* *}$ \\
\hline
\end{tabular}

$*$ sig. at $10 \%$ level, $* *$ sig. at $5 \%$ level, and ${ }^{* * *}$ sig. at $1 \%$ level

Finding the significant different CAAR for the year which it compared with is necessary, and Table 5 provides the Ordinary Least Square (OLS) regression result. The results reveal that only 2008 and 2009 exhibit negative and significant coefficients. The negative and significant abnormal returns of IPOs suggest that the market reacts negatively towards these IPOs. This might be also due to the global financial crisis that started to impact New Zealand economy in the mid-2006 and beginning of 2007; investors incurred losses on equity investments (both directly held and via managed funds). These losses can persist long-term, or even be permanent (in those cases where a company fails). For example, in 2007 Telecom's market value declined about $\$ 5.5$ billion since the start of 2007, and was a multiple of the losses from finance company failures. The decline in the market indices and stock prices on the NZSX also lead to negative sentiments toward new securities issuance. In addition, the long-term bond had higher interest rates compared to short-term bonds, which resulted in the changes in the investor preference of securities instruments. Further, the increased interest rate resulted in the fall of the bond value and stock value, and so to for IPOs which yielded negative abnormal returns.

Table 5. OLS Regression results

\begin{tabular}{lcc}
\hline & Coefficient & Std.Error \\
\hline Constant & 0.0010 & 0.0011 \\
2006 & -0.0009 & 0.0013 \\
2007 & -0.0020 & 0.0016 \\
2008 & $-0.0026^{*}$ & 0.0014 \\
2009 & $-0.0027^{*}$ & 0.0014 \\
2010 & (Omitted) & (Omitted) \\
\hline Obs. & 1380 & \\
Wald Chi2 & 5.89 & \\
Prob.>Chi2 & 0.2074 & \\
\hline
\end{tabular}

*sig. at $10 \%$ level, ${ }^{*}$ sig. at $5 \%$ level, and ${ }^{* * *}$ sig. at $1 \%$ level 


\section{Macrothink Institute ${ }^{\mathrm{TM}}$}

Figure 1 and Figure 2 depict the average abnormal returns for 60 trading days using market adjusted returns and market model respectively. As can be seen, apart from 2010, the average abnormal returns for all years fluctuate between -0.04 and 0.03 , suggesting less outlier in the observation. Another explanation for these negative fluctuation abnormal returns is that while the beneficiaries from the crisis will be few in number, there will have been some. A few will have been astute enough early in, or ahead of, the crisis to have sold equities and bought prime fixed interest bonds which, (with falling interest rates) will have increased in value, and thus contributed to the negative abnormal returns of IPOs. Furthermore, 30 finance companies went into receivership or liquidation in New Zealand, and these finance company failures compounded the conditions of market stability, as the capital market is related directly to the finance companies. In addition, the decline of Growth Domestic Product (GDP), the increase of the inflation rate, the increase of unemployment added to the NZ economic uncertainty combined to lower market confidence of investors regarding the prospect of new firms (IPOs).

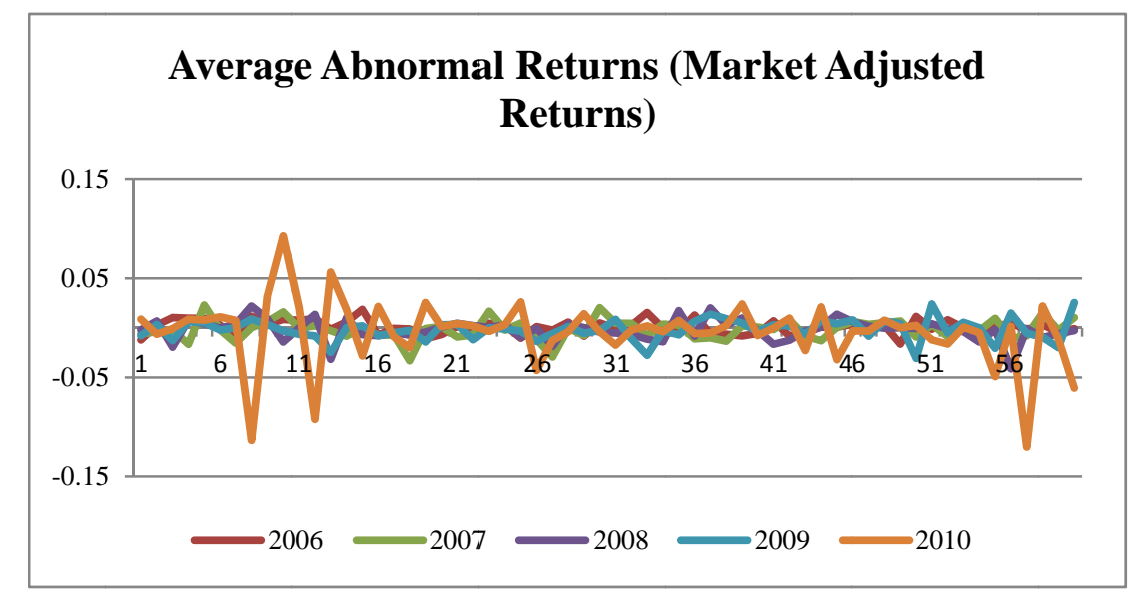

Figure 1. Average abnormal returns for 60 trading days

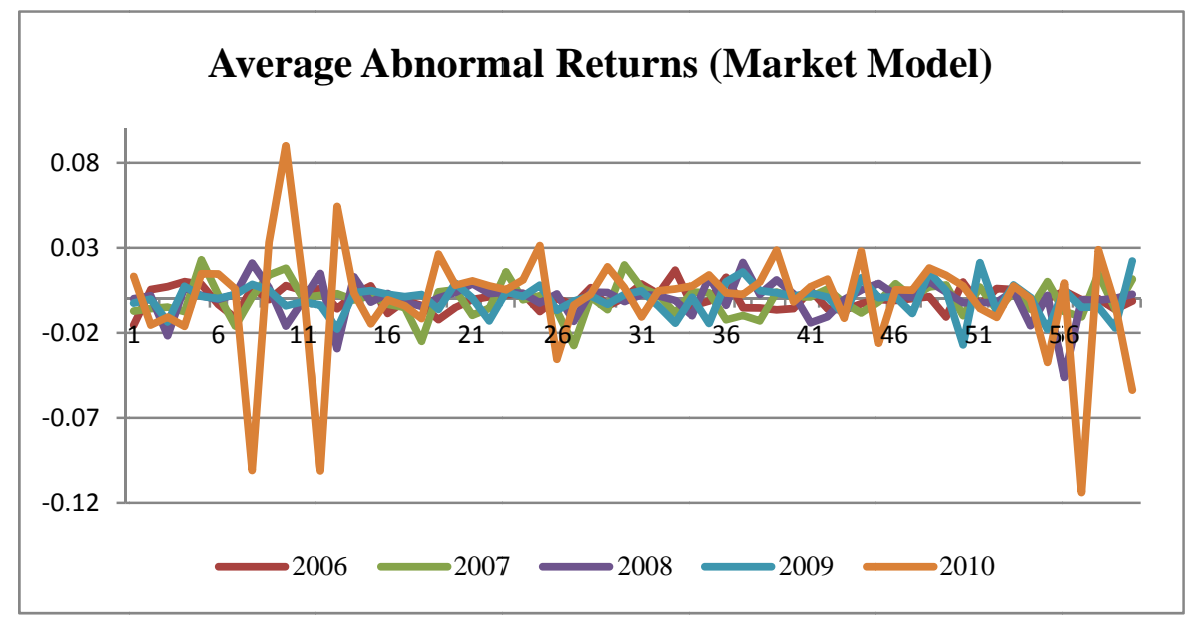

Figure 2. Average abnormal returns for 60 trading days 


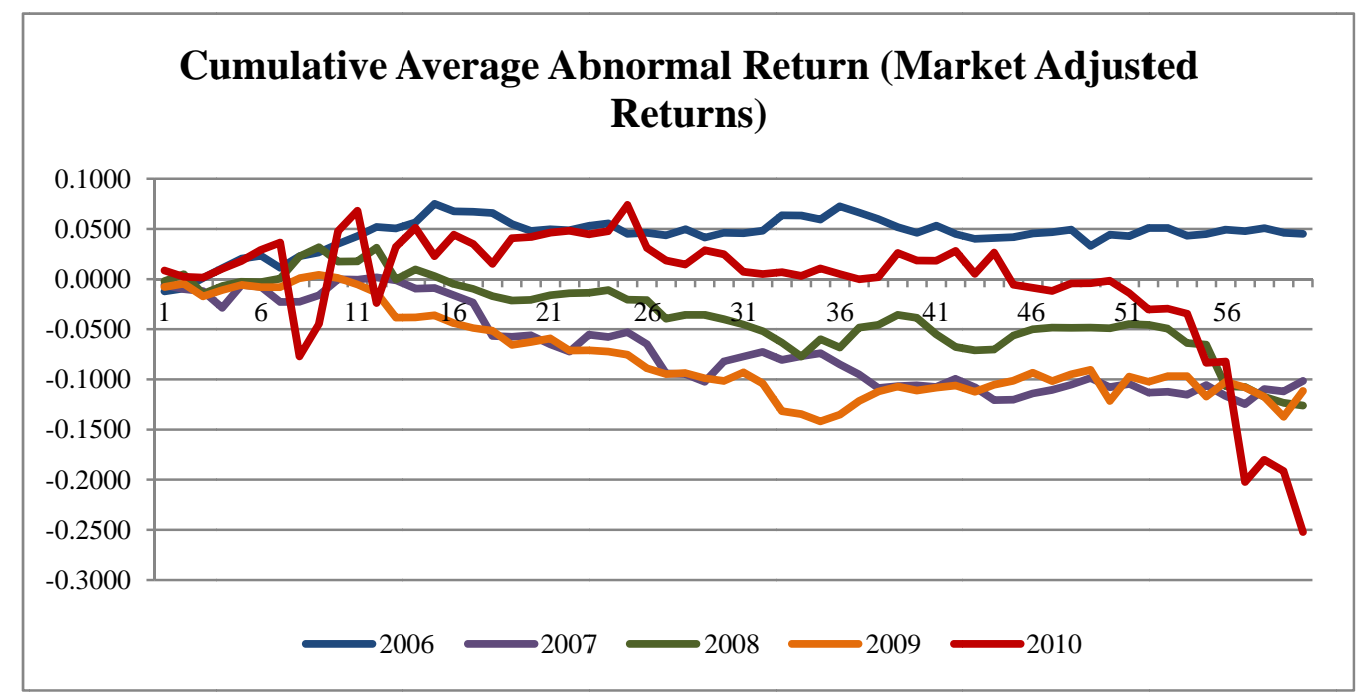

Figure 3. Cumulative average abnormal returns for 60 trading days

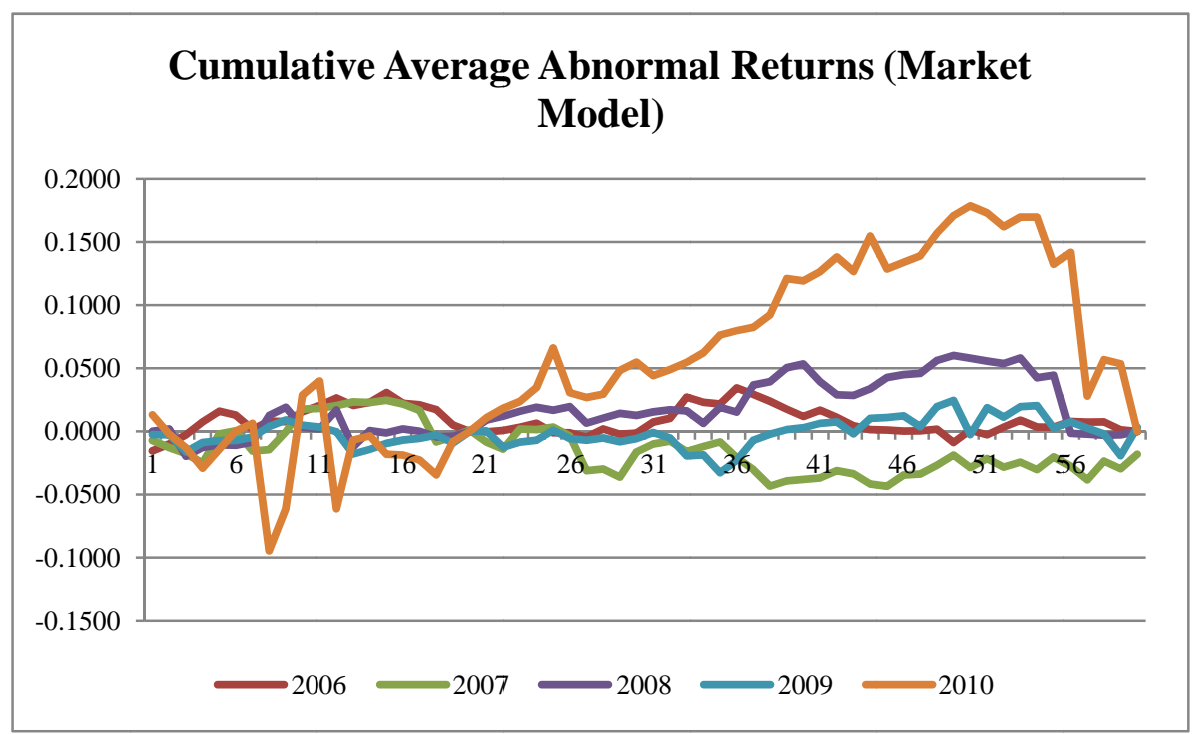

Figure 4. Cumulative average abnormal returns for 60 trading days

Figure 3 and Figure 4 exhibit the cumulative average abnormal returns for 60 trading days using market adjusted returns and market model respectively. Figure 3 shows that apart from the CAAR for 2006, all coefficients for the CAAR in the years observed tend to experience a negative cumulative average abnormal return, suggesting that there was turmoil in the economic condition which impacted the IPOs performance after 2006. However, using a different method provides different results, which can be seen in Figure 4 in which all the CAAR were observed to move upward. The different patterns of the CAAR movements are 
due to that market model counting on the beta being estimated, and the beta tends to level up the average abnormal returns, hence resulting more positive returns.

\section{Conclusions}

The phenomenon of abnormal initial return of IPOs has been well documented by the literature. Based on investor rationality in an efficient market, the first day trading price is supposed to be the fair value of IPOs, but the offer price is considered to be set below the fair value. In this case IPOs are underpriced and exhibit positive abnormal returns in the short run. However, this phenomenon seems not to fit New Zealand IPOs, as New Zealand IPOs exhibit negative abnormal returns for the first few days after listing day. This finding is consistent with those reported from other countries. Prior research reported that the negative abnormal returns for IPOs in Germany, which is $-12.1 \%$ and $-27.0 \%$ for Japanese IPOs.

This study examines the short-term IPOs' performance of listed firms on the NZSX during the period 2006 to 2010. The findings suggest that returns on the short-term performance of IPOs are varied over the 20 trading days and 60 trading days after the listing day. The average abnormal returns until the fifth trading day are negative, suggesting that investors who bought IPOs at the close of trading on the first day would have lost against the market performance. The results reveal a continuing deterioration in short-term performance over 20 trading days and 60 trading days. In addition to the market model's 20 trading days, the results show no significant difference between 20 trading days and 60 trading days using two different methods of abnormal return calculation. Further, the results exhibit significant coefficients for all years in which they are compared, and thus this study rejects the null hypothesis that the $\mathrm{CAAR}_{2006(1, T)}$ is not significantly different from the $\mathrm{CAAR}_{2007(1, T)}$, and so on. Hence, it can be concluded that there is a significant difference of the CAAR for the years compared. Further, the OLS regression results reveal that only 2008 and 2009 exhibit negative and significant coefficients

An immediate implication of the result is that investors acted cautiously to avoid a loss, as the market condition was unfavourable because of the global financial crisis. The evidence is consistent with the economic condition during 2008 and 2009, where the US subprime crisis of 2006 and 2007 had impacted on other countries, by spreading all over the world and becoming a global financial crisis. However, other causes seem to be possible in contributing to the difference. For example, setting the offering price too high may result in negative sentiment of the markets; as a result this impacts on IPOs' performance. However, the short-term IPOs' performance alone is unable to explain the overall performance; thus, long-term IPO performance analysis may be needed to support the short-term performance of IPOs. Overall, New Zealand IPOs outperformed on a short-run basis during the global financial crisis/situation.

Despite the current global gloominess, financial crises and recessions do not last forever. The future in New Zealand is looking bright. The new Government has demonstrated, during its short time in office, that it is willing to implement the necessary changes to set up a framework that will stimulate confidence and put the country on the road to recovery. It has 


\section{Macrothink}

Asian Journal of Finance \& Accounting

ISSN 1946-052X

2012, Vol. 4, No. 2

proven that it can adapt swiftly to amend and introduce policies that will encourage business back to a more normal environment.

\section{Limitations}

The findings of this study are restricted to the limitation of the data, which was collected through publicly available data sources such as annual reports and other databases. If there were any problems relating to data disclosures or professional accounting practices, then that would limit the validity of the findings. The number of IPOs on the New Zealand stock exchange from 2006 to 2010, which comprised only 23 IPOs, limits the size of the sample. Further, the conclusions are limited to the event during the global financial crisis only, hence any other events which affected an IPO's price were not considered in this study.

\section{References}

Aggarwal, R., \& Rivoli, P. (1990). Fads in the initial public offering market. Financial Management, 19, 45-57.

Ball, R., \& Brown, P. (1968). An empirical evaluation of accounting income numbers. Journal of Accounting Research, 6, 159-178.

Binder, J. J. (1985). On the use of the multivariate regression model in event studies. Jounral of Accounting Research, 23(1), 370-383.

Blume, M. E. (1975). Betas and their regression tendencies. The Journal of Finance, 30(3), 785-795.

Brown, S. J., \& Warner, J. B. (1980). Measuring security price performance. Journal of Financial Economics, 8, 205-258.

Brown, S. J., \& Warner, J. B. (1985). Using daily stock returns: The case of event studies. Journal of Financial Economics, 14, 3-31.

Capital Market Development Taskforce. (2009). Ministry of Economic Development. Retrieved from http://www.med.govt.nz/business/economic-development/capital-market-development-taskfo rce

Castillo, A. (2004). The announcement effect of bond and equity issues: Evidence from Chile. Estudios de Economía, 31(2), 177-205.

Chandra, R., Moriarity, S., \& Willinger, G. L. (1990). A Re-examination of the power of alternative return generating models and the effect of accounting for cross-sectional dependencies in event studies. Journal of Accounting Research, 28(2), 398-408.

Dolley, J. C. (1933). Characteristics and procedure of common stock split-ups. Harvard Business Review, 316-326.

Fama, E. F., Fisher, L., Jensen, M. C., \& Roll, R. (1969). The adjustment of stock prices to new information. International Economic Review, 10(1), 1-21. 
Finn, F. J., \& Higham, R. (1988). The performance of unseasoned new equity issues stock exchange listings in Australia. Journal of Banking and Finance, 12, 333-351.

Firth, M. (1997). An analysis of the stock market performance of new issues in New Zealand. Pacific-Basin Finance Journal, 5, 63-85.

Gibbons, M. R. (1982). Multivariate tests of financial models: A new approach. Journal of Financial Economics, 10(1), 3-27. http.//dx.doi.org/10.1016/0304-405X(82)90028-9

Gong, N., \& Sekhar, C. (2001). Underpricing of privatised IPOs: The Australian experience. Australian Management Journal, 26(2), 91-106. http.//dx.doi.org/10.1177/031289620102600201

Husson, B., \& Jacquillat, B. (1989). French new issues, underpricing and alternative methods of distribution. In M.C. Rui, B. Guimaraes, G. Kingsman \& S. J. Taylor (Eds.), A Reappraisal of the Efficiency of Financial Markets Springer-Verlag, 349- 368.

Ibbotson, R., Sindelar, J., \& Ritter, J. (1994). The market's problems with the pricing of initial public offerings. Journal of Applied Corporate Finance, 7, 66-74. http.//dx.doi.org/10.1111/j.1745-6622.1994.tb00395.x

Keasey, K., \& Short, H. (1992). The underpricing of initial public offerings: Some UK evidence. International Journal of Management Science, 20, 457-466. http://dx.doi.org/10.1016/0305-0483(92)90020-8

Kunz, R. M., \& Aggarwal, R. (1994). Why initial public offerings are underpriced: Evidence from Switzerland. Journal of Banking and Finance, 18, 705-723.

Lee, P. J., Taylor, S. L., \& Walter, T. S. (1996). Expected and realized returns for Singaporean IPOs: Initial and long-run analysis. Pacific-Basin Finance Journal, 4, 153-180.

Levis, M. (1993). The long-run performance of initial public offerings: The UK experience 1980-1988. Financial Management, 22(1), 28-41.

Ljungqvist, A., \& Wilhelm, W. J. (2003). IPO pricing in the dot-com bubble. Journal of Finance, 58, 723-752. http://dx.doi.org/10.1111/1540-6261.00543

Loughran, T., \& Ritter, J. R. (1995). The new issues puzzle. Journal of Finance, 50, 23-52.

Loughran, T., Ritter, J. R., \& Rydqvist, K. (1994). Initial public offerings: International insights. Pacific-Basin Finance Journal, 2, 165-99.

Loughran, T., Ritter, J., \& Rydqvist, K. (2006). Initial public offerings: International insights. Pacific-Basin Finance Journal, 2, 165-199.

MacKinlay, A. C. (1997). Event studies in economics and finance. Journal of Economic Literature, 35, 13-39.

NZ Roy Morgan Consumer Confidence Survey 2009. (2009). Australia New Zealand Bank. Retrieved

from: 
http://www.anz.co.nz/commercial-institutional/economic-markets-research/consumer-confide nce/

Reilly, F. K. (1977). New issues revisited. Financial Management, 6, 28-42.

Ritter, J. (1991). The long-run performance of initial public offerings. Journal of Finance, 46, 3-27.

Ritter, J., \& Welch. (2002). A review of IPO activity, pricing, and allocations. Journal of Finance,. 57,1795-1828. http://dx.doi.org/10.1111/1540-6261.00478

Ritter, J.R. (1998). Initial public offerings. Contemporary Finance Digest, 2(1), 5-30.

Rock, K. (1986). Why new issues are underpriced? Journal of Financial Economics, 15, 187-212.

Shiller, R. J. (1990). Speculative prices and popular models. The Journal of Economics Perspectives, 4( 2), 55-65.

Teoh, S., Welch, I., \& Wong, T. (1998). Earnings management and the post-issue underperformance in seasoned equity offerings. Journal of Financial Economics, 50, 63-99. http://dx.doi.org/10.1016/S0304-405X(98)00032-4

The NZX Listing Rules. (2010). The New Zealand Stock Exhange. Retrieved from: https://www.nzX.com/files/static/NZSX_NZDX_Listing_Rules.pdf.

The Securities Amendment Act 2009. (2009). New Zealand Legislation. Retrieved from: http://www.legislation.govt.nz/act/public/2009/0023/latest/DLM1827104.html

Vos, E., \& Cheung, J. (1992). New Zealand IPO underpricing: The reputation factor. Small Enterprise Research, 1(1), 13-22. http://dx.doi.org/10.5172/ser.1.1.13

Welch, I. (1992). Sequential sales, learning, and cascades. Journal of Finance, 47, 695-732. 